\title{
Insolubility of milk powder products - A minireview
}

\author{
Alan J. BALDwIN* \\ Fonterra Research Centre, Fonterra Co-operative Group Ltd., Private Bag 11 029, \\ Palmerston North, New Zealand

\begin{abstract}
Received 17 April 2009 - Revised 5 November 2009 - Accepted 30 November 2009
Published online 19 January 2010
\end{abstract}

\begin{abstract}
In this paper, the formation of insolubility in milk powder is described, and the factors affecting the reaction are discussed. The zone in which casein proteins are most sensitive to heat is in the moisture range that occurs during spray drying. The rate of reaction has been determined and shows differences of orders of magnitude with the moisture content. The effect of chemical reagents on the extent of reaction gives insights into the chemical bonds that inhibit hydration. Information on the drying of casein products and individual proteins is used to infer that the withdrawal of moisture from casein proteins and the concentration of divalent cations during drying lead to alterations in the conformation of proteins that have an adverse effect on their rehydration during reconstitution. Further work to fully characterise these effects is required.
\end{abstract}

\section{spray drying / powder / casein / insolubility / kinetics}

摘要 - 乳粉产品的不溶性一综述。本文探讨了不溶性乳粉的形成原因及其影响因素。在喷 雾干燥过程中酪蛋白对热最敏感的区域是在某一水分范围内。根据已知的反应速率，可以 看出在不同的水分含量下蛋白变性的程度不同。从化学成分对反应程度的影响上可以看出 化学键合作用可以有效地抑制水合作用。根据干燥的酪蛋白产品和每种蛋白质的特性可以 推断由于干燥导致得水分子从酪蛋白中脱出和二价阳离子的浓缩使得蛋白质构象发生 改变, 进而使蛋白质复原时的再水化作用降低。关于更多的影响乳蛋白再水化作用的 因素有待进一步研究。

\section{干燥 / 蛋白产品 / 酪蛋白 / 不溶性 / 动力学}

Résumé - Insolubilité des poudres laitières - une mini-revue. L'apparition de l'insolubilité des poudres laitières est décrite et les facteurs affectant cette réaction sont discutés dans cet article. La zone dans laquelle les caséines sont les plus sensibles à la chaleur se situe dans la gamme d'humidité intervenant au cours du procédé de séchage par atomisation. La vitesse de réaction a été déterminée et montre des différences d'ordres de grandeur des taux d'humidité. L'effet des réactifs chimiques sur l'étendue de la réaction donne un aperçu des liaisons chimiques qui inhibent l'hydratation. On peut déduire de l'information obtenue sur le séchage des caséines et des protéines individuelles que l'élimination de l'humidité des caséines et la concentration en cations divalents au cours du séchage conduisent à des modifications de la conformation des protéines qui peuvent avoir des effets négatifs sur leur réhydratation au cours de la reconstitution des poudres. Un travail ultérieur est nécessaire pour caractériser complètement ces effets.

séchage par atomisation / poudre / caséine / insolubilité / cinétique

*Corresponding author (通讯作者): alan.baldwin@fonterra.com 


\section{MILK COMPONENTS}

The major components of milk are carbohydrate (lactose, in solution), fat (colloidal emulsion), minerals (in solution and in the casein micelles), whey proteins (20\% of the protein) and casein proteins. Proteins are formed from a number of amino acids; the hydrophilicity of these groups is estimated to range from $0 \mathrm{kcal} \cdot \mathrm{mol}^{-1}$ for glycine to $22.3 \mathrm{kcal} \cdot \mathrm{mol}^{-1}$ for arginine [11]. The backbone of the chain is also hydrated. The whey proteins exist in milk as small units (monomers or dimers). During the heat treatment of milk, at the beginning of the evaporation process, the whey proteins change their conformation, associate and may react with $\kappa$-casein $[10,37]$.

Most of the casein in milk exists as micelles, with an average diameter of about $200 \mathrm{~nm}$ [12]. Some models have proposed arrangements of the proteins within the micelle as clusters or sub-micelles $[16,25,45]$, but the physical arrangement is still subject to much debate $[12,40]$. One of the models of casein in milk is as a cluster of several hundred casein molecules, with the proteins arranged with a dense hydrophobic core, in which most of the hydrophobic parts of the casein molecules are buried, and a more loosely packed hydrophilic outer layer, containing most of the acidic (carboxylic and phosphoric) groups and some of the basic groups [47]. What is agreed is that the micelles are stabilised in water by the hydrophilic portions of $\kappa$-casein, and to a lesser extent $\beta$-casein, proteins. It has been clearly demonstrated that the hydrophilic "tail" of $\kappa$-casein on the surface of the micelle stabilises the micelle in solution.

A number of effects come into play as water is removed and the concentration of the milk is increased [48]. The charged species move closer and are more likely to interact. The salt equilibria change with concentration. However, the calcium activity increases only slightly, because calcium phosphate is saturated in milk and the quantity of calcium associated with the casein micelles increases. The ratio of monovalent cations to divalent cations increases. The $\mathrm{pH}$ decreases somewhat. Because of these changes in the ionic environment, the orientation of the protein chains may change.

The milk powder industry can be regarded as comprising the steps of removing most of the water (dehydration), prolonged storage and then replacing the water (hydration), with the components restored to close to their original state. With reconstitution in water at ambient temperatures and soluble proteins, the system can take 2 or $3 \mathrm{~h}$ to equilibrate to near the final equilibrium values of ionic calcium and phosphorus [5, 32]. The equilibration of components usually takes place with soluble particles, as, over the years, the drying conditions for skim milk powder (SMP) have been optimised. In this paper, we are concerned with the role of the hydration of the caseins in milk powders when the conditions are not as ideal, either because of the particular drying conditions used or because of the considerably higher protein content of the product. In spray drying, the whey proteins are generally unaffected [23], and the insoluble material arising from drying is primarily casein [31].

Reconstitution of milk powders may be undertaken at temperatures ranging from $5{ }^{\circ} \mathrm{C}$ (milk extension) to ambient temperature (recombining and laboratory tests) to $40-55^{\circ} \mathrm{C}$ in commercial recombining operations (optimum temperature) [4, 14]. Consumer reconstitution is undertaken over the temperature range from $5{ }^{\circ} \mathrm{C}$ for water from the refrigerator to $85{ }^{\circ} \mathrm{C}$ for boiling water poured into a container. The extent to which milk powders are insoluble in water has traditionally been measured in the milk powder industry using an insolubility test (solubility index, SI), originally developed by the American Dry Milk Institute [3] and adopted by the International Dairy Federation [27]. Powder is reconstituted 
in water at ambient temperature $\left(24^{\circ} \mathrm{C}\right)$ with a high-speed mixer for $90 \mathrm{~s}$. The undissolved particles are measured by centrifuging the solution and measuring the sediment volume (in millilitres) in tapered and graduated centrifuge tubes. A test based on measuring the total solids of the total solution and the supernatant has been employed in the protein industry $[6,35]$.

In this paper, the insolubility phenomenon of milk powder in ambient temperature water $\left(24{ }^{\circ} \mathrm{C}\right)$ is quantified, and possible explanations for its occurrence are explored. Included within the scope of milk powder are (a) the traditional milk powder products (SMP and whole milk powder (WMP)) and (b) the higher milk protein products such as milk protein concentrate (MPC ${ }^{1}$ ) made by membrane processes [8] and native phosphocaseinate products [43].

\section{CHARACTERISATION OF THE INSOLUBILITY REACTION}

The effect of heat on casein has been investigated at laboratory scale. Pioneering work was done by Wright [49]; he assembled the rates of insolubility formation for powder at a moisture content of $13 \%$ and for evaporated milks in the range of $62-72 \%$ moisture (28-38\% total solids) and estimated the rates at intermediate moisture contents. More recently, a few studies have been done on dry powders [29, 36]. However, it is difficult to study experimentally the intermediate moisture zone.

Studies of the insolubility phenomenon were undertaken at the Fonterra Research Centre. Moist material was produced using SMP and MPC70 as base products. With the moist materials, the reaction followed an S-shaped curve, starting slowly, accelerating rapidly and then levelling off, as illustrated in Figure 1. The reaction curve

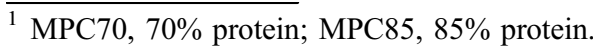

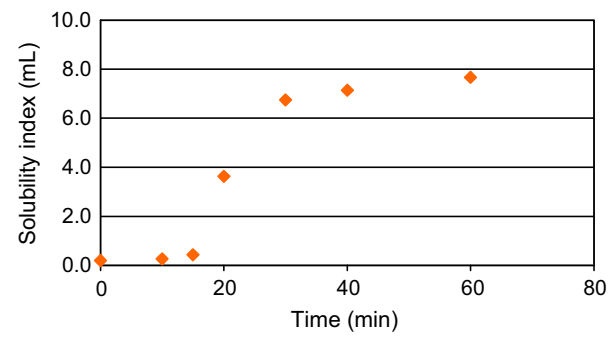

Figure 1. SMP (moisture content $23 \mathrm{~g} \cdot 100 \mathrm{~g}$ product $^{-1}$ ) heat treated at $30{ }^{\circ} \mathrm{C}$. Development of SI $(\mathrm{mL})$ with heating time $(\mathrm{min})$.

illustrated is typical of the behaviour exhibited by moist milk powder material.

Several different techniques were used to form the moist materials. Humidification was best suited to producing a product with a moisture content of up to about $10 \mathrm{~g} \cdot 100 \mathrm{~g}$ product $^{-1}$. Freeze drying produced materials in the required moisture range. However, as the materials showed a wide range of moisture content depending on the position on the drier tray, an equilibration step was required. It was found that adding powder to a reconstituted concentrate was the method that gave the most control over the final moisture content of the powder.

Products with moisture contents (wet basis) in the range from 10 to $55 \mathrm{~g} \cdot 100 \mathrm{~g}$ product $^{-1}$ were produced. The rates of development of insolubility in the moist products were studied in the temperature range from 5 to $55^{\circ} \mathrm{C}$; at any higher temperature, the rates of reaction were too fast to follow with the test procedure employed. The SI sediments $\left(24^{\circ} \mathrm{C}\right)$ were expressed on the basis of dry matter in the moist products. The rates of development of insolubility in SMP are shown in Figure 2 [9].

The trials with different moisture contents demonstrated that the zone of moisture for maximum sensitivity to heat was from 15 to $40 \mathrm{~g}$ water $100 \mathrm{~g}_{\text {product }}{ }^{-1}$. To reach an insolubility of $6 \mathrm{~mL}$ at $50{ }^{\circ} \mathrm{C}$ took $50 \mathrm{~h}$ 


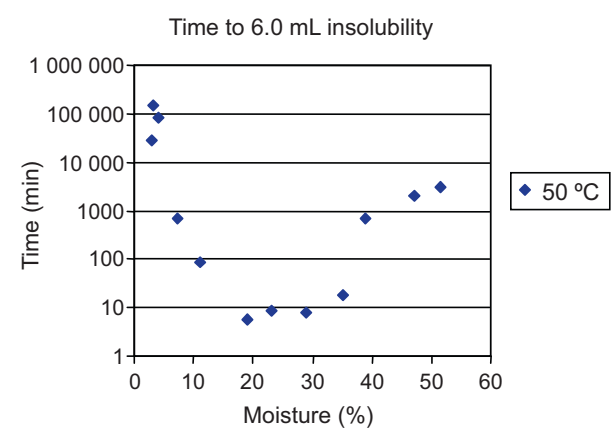

Figure 2. Rate of development of insolubility in SMP. Reprinted from [9].

in concentrate and 70 days in dry powder compared with $10 \mathrm{~min}$ in the sensitive zone. Thus, in the moisture-sensitive zone, the rates of insolubility development at $50{ }^{\circ} \mathrm{C}$ were 100 times faster than those in concentrate and 10000 times faster than those in dry powder.

The reaction rate was faster with higher protein contents. It was found [9] to be 10 times faster with MPC70 (double the protein content of SMP) than with SMP.

The effect of temperature on the rate of development of insolubility followed an Arrhenius plot (correlation coefficients $r^{2}=0.98$ or greater), yielding temperature coefficients of $2-3$ per $10{ }^{\circ} \mathrm{C}$ [9]. The temperature coefficients allow estimates of rates of insolubility formation to be made at temperatures higher than those used for the measurements. The information can thus be used in computational fluid dynamic models to simulate insolubility effects in pilot plant and commercial equipment.

\subsection{Behaviour of moist material}

The moist product was stored at $-85^{\circ} \mathrm{C}$. When it was stored at $-18{ }^{\circ} \mathrm{C}(255 \mathrm{~K})$, slow increases in insolubility with storage time were observed. For instance, with a product of moisture content $36 \mathrm{~g} \cdot 100 \mathrm{~g}^{-1}$, fresh material had an SI of $0.2 \mathrm{~mL}$, whereas a 4-day-old material had an SI of $3.0 \mathrm{~mL}$. Water may still be active at $-18{ }^{\circ} \mathrm{C}$, as it has been deduced that the water associated with proteins freezes at very low temperatures [30].

The texture of the material determines how it can be processed. At a moisture content of $19 \mathrm{~g} \cdot 100 \mathrm{~g}^{-1}$, the material was brittle and could be easily grated. At a moisture content of $25 \mathrm{~g} \cdot 100 \mathrm{~g}^{-1}$, the material, after treatment for $2 \mathrm{~h}$ at $-18{ }^{\circ} \mathrm{C}$, could be grated; the final product was like breadcrumbs. At a moisture content of $35 \mathrm{~g} \cdot 100 \mathrm{~g}^{-1}$, the material was pliable but sticky. At higher moisture contents $\left(40 \mathrm{~g} \cdot 100 \mathrm{~g}^{-1}\right)$, the material was soft, could be extruded through an icing piping bag and had a very sticky surface. The stickiness of the materials reflected either lactose above the glass transition temperature [41] or, for high protein products, unsatisfied bonds [15].

\section{HYDRATION OF DAIRY PROTEIN PRODUCTS}

\subsection{Spray drier settings}

The insolubility of SMP in drying plants is mainly controlled by two means $[22,38]$ : (a) control of the temperature of the air in the drying chamber to influence the temperatures experienced by the droplets; products made with low temperatures exhibit improved solubility and (b) a decrease in particle size, which affects the drying time of the particle. A large change in atomisation requires large increases in energy and leads to markedly changed powder properties; SMP becomes dusty and WMP becomes more cohesive.

Similar principles to those for drying SMP can be applied for drying high protein products such as MPC, but the materials are more sensitive and both drying time and drying temperature should be optimised [9]. With optimised conditions, soluble high protein materials can be obtained. However, 
these materials show a decrease in solubility with storage time [6], and this loss is very dependent on the storage temperature.

\subsection{Particle solubilisation}

When particles become less soluble, they are visible in the reconstituted powder solution. The effects of the insolubility on the delay in solubilisation can be measured by the particle size distributions of the reconstituted liquids. The particles may take up to $8 \mathrm{~h}$ or longer to dissolve [17, 28, 33]. Using laser light scattering, two protein powders differing in solubility test results showed marked differences in their size distributions (Fig. 3) 15 min after the start of reconstitution. One powder was still totally in the particulate region, greater than $1 \mu \mathrm{m}$, whereas the other powder was predominantly in the sub-micron micellar region. The hydrating but undissolved particles were of similar size to the particles in the original powder ${ }^{2}$.

\subsection{Bonding of proteins}

The bonds causing the delay of solubilisation of SMP and MPC particles have been investigated.

McKenna [33] studied transmission electron micrographs of liquids from the different stages of manufacture of MPC85 and of reconstituted powders from a storage trial. He observed movement of some protein out of the micelle and a monolayer of close-packed micelles ("skin") at the surface of the particles. He postulated the crosslinking of micelles by non-micellar proteins and by the close association of micelles at the surface.

In SDS-PAGE (sodium dodecyl sulphate and polyacrylamide gel electrophoresis) investigations of freshly dried and stored MPC, it was found that the insolubility

\footnotetext{
${ }^{2}$ Determination of powder particle size by laser light scattering in air, refractive index $=1.46$ and absorption $=0$.
}

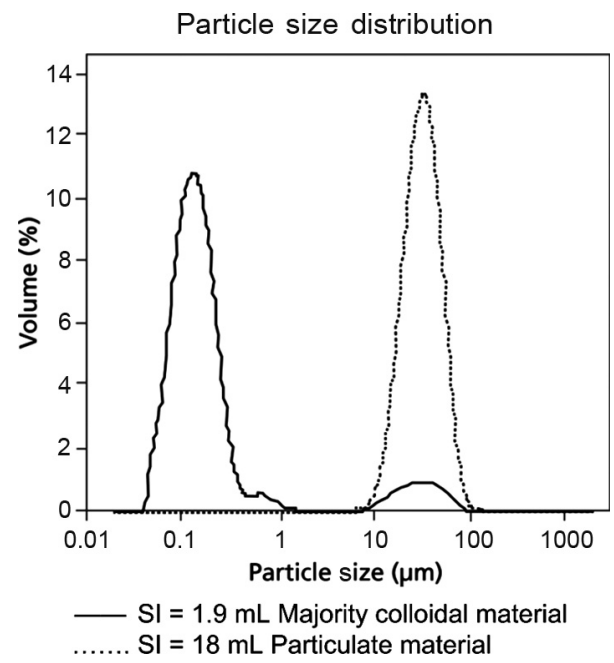

Figure 3. Particle size distributions of $(-)$ mostly soluble MPC85 and (......) mostly insoluble MPC85, determined using a laser light scattering instrument. (Malvern Instruments Mastersizer 2000 with Hydro 2000 liquid cell, dispersant water, particle refractive index $=1.36$ and absorption $=0.001$.)

did not arise from covalent bonding and therefore it was deduced to be due to weak non-covalent bonds - hydrophobic interactions or hydrogen bonds - that were dissociated by the SDS $[6,24]$.

The insolubility in the reconstitution process was investigated directly by determining the effects of adding reagents in place of reverse osmosis water in the dissolution step of the SI test. SMP heat treated in the laboratory was treated with the reagents such as urea, dithiothreitol (DTT), SDS, Tween 20 and sodium citrate. The concentrations and the bonds that were broken are given in Table I [46].

The results at (a) an initial stage of insolubility formation and (b) mid-way through the process are given in Figure 4 (Baldwin, unpublished results, 2002). In the initial stages of the insolubility formation, sulphydryl, ionic and hydrogen bonds and hydrophobic interactions all appeared to be involved. 
Table I. List of reagents and bonds disrupted by the reagents.

\begin{tabular}{lcl}
\hline Reagent & Concentration & \multicolumn{1}{c}{ Bond broken } \\
\hline Urea & $3 \mathrm{~mol} \cdot \mathrm{L}^{-1}$ & $\begin{array}{l}\text { Hydrogen } \\
\text { a }\end{array}$ \\
DTT & $0.01 \mathrm{~mol} \cdot \mathrm{L}^{-1}$ & $\begin{array}{l}\text { Sulphydryl } \\
\text { SDS }\end{array}$ \\
$0.1 \mathrm{~g} \cdot 100 \mathrm{~g}^{-1}$ & $\begin{array}{l}\text { Hydrophobic (HP) } \\
\text { (charge) }\end{array}$ \\
Tween 20 & $0.45 \mathrm{~g} \cdot 100 \mathrm{~g}^{-1}$ & $\begin{array}{l}\text { Hydrophobic (HP) } \\
\text { (non-ionic) }\end{array}$ \\
Citrate & $0.02 \mathrm{~mol} \cdot \mathrm{L}^{-1}$ & Ionic \\
\hline
\end{tabular}

${ }^{a}$ Also weakens hydrophobic interactions.

With the insolubility reaction well underway, the quantity of sediment appeared to be mostly dominated by ionic and hydrogen bonds. The solubility test study and the PAGE studies showed differences in the effectiveness of SDS. This probably arose from the difference in the concentration of the SDS (concentration SI test, $0.1 \mathrm{~g} \cdot 100 \mathrm{~g}^{-1}$; concentration PAGE studies, $10 \mathrm{~g} \cdot 100 \mathrm{~g}^{-1}$ ).

A large amount of water is associated with the micelle; it could be physically trapped or it could be loosely bound. The ratio of water to protein at the point of maximum rate of formation of insolubility is approximately mass water:mass protein $=1: 1$. This is equivalent to a molar ratio of 15 water molecules per amino acid residue. As water is withdrawn during dehydration, the hydration will be reduced and the orientation of the various amino groups and the configuration of the looped protein will be altered [13]. The optimum arrangement will also be affected by the ionic charges arising from the concentration of the mineral ions. As the water concentration is reduced further, the proteins will become less plasticised and will not be able to reorientate as quickly, and the rates of formation of insolubility will become increasingly slower. These concentration effects explain the greater stability at high and low moisture contents.

The degree of plasticisation of proteins by solvents depends on the moisture content and the temperature of the material. For a number of proteins, the protein molecule will rearrange more rapidly at temperatures above $230 \mathrm{~K}$. Gregory [19] has presented a comprehensive review of the plasticisation of proteins by solvents. To explain the results from a number of instrumental techniques, a model was developed in which some regions of the protein structure are rigid and others are more flexible and primarily involved in the conformational change.

Rearrangement of protein conformations to more hydrophobic forms is likely to be at the heart of the casein protein insolubility phenomenon. Changes in the conformation of some individual proteins during dehydration have been demonstrated by a number of workers using Fourier transform infrared (FTIR) analysis [2, 39]. For instance, $\alpha$-casein changed from an arrangement in solution that was unstructured to an arrangement in powder that had elements of $\beta$-sheet structure [39].

\subsection{Role of lactose}

As a consequence of the increased protein content of MPCs, their lactose content is greatly reduced relative to that of SMP (Tab. II). The role of sugars in the drying process has been investigated in studies of the lyophilisation (freeze drying) of individual proteins. It has been demonstrated that carbohydrate has a role during dehydration in maintaining the native structure of the protein $[1,2,39]$. It has been suggested that the sugars can hydrogen bond to the dried protein in place of the water molecules that are lost as the polar hydration shell is removed.

From these insights, it can be deduced that, in milk products such as SMP and WMP, lactose has a role in the prevention of protein interactions, both by acting as a mechanical spacer and by hydrogen bonding to the protein chain. In addition, being hydrophilic, lactose can act as a pathway for moisture transfer within the micelle in the rehydration process. 
(a)

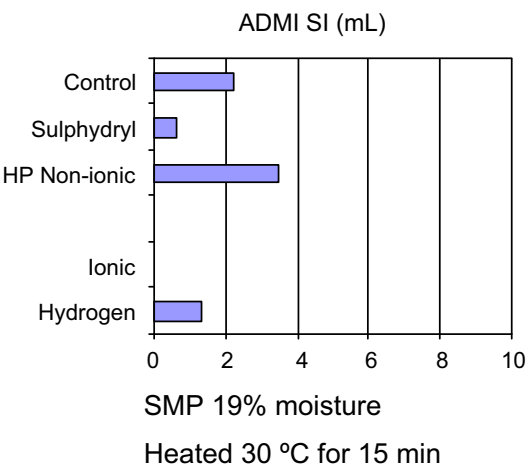

(b)

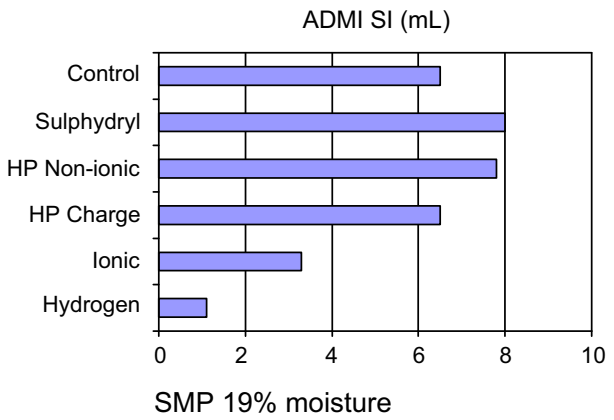

Heated $30^{\circ} \mathrm{C}$ for $120 \mathrm{~min}$

Figure 4. Effect of reagents on SI sediment. Material: SMP, moisture content 19\%. (a) Heat treatment at $30{ }^{\circ} \mathrm{C}$ for $15 \mathrm{~min}$. (b) Heat treatment at $30{ }^{\circ} \mathrm{C}$ for $2.0 \mathrm{~h}$. HP $=$ Hydrophobic. Reduced length of bar indicates more effect of reagent.

\section{MODIFICATION OF COMPOSITION AND THE ROLE OF MINERAL IONS}

High protein powders are manufactured by ultrafiltration (UF), which results in an increase in protein and a decrease in lactose and calcium in the retentate (on a protein basis). The solubility of MPCs in cold water is low, but the solubility of high protein powders can be improved by producing modified products with changed mineral composition. One process is to take UF retentate and, using an ion exchange column, to exchange sodium for calcium [34].

The products from this treatment are more viscous than untreated products, and this requires an adjustment of the evaporator conditions and a reduction in the total solids of the concentrate at drying. The products are some of the way to exhibiting the behaviour of sodium caseinate, in which the proteins are in a suspension of individual molecules rather than in a micelle.

Another approach to changing the mineral composition is to add salt $(\mathrm{NaCl})$ to the concentrate prior to spray drying [35]. These processes result in improved solubility and
Table II. Typical compositions of protein products on a dry matter basis.

\begin{tabular}{lrrr}
\hline Component & SMP & MPC70 & MPC85 \\
\hline Protein $\left(\mathrm{g} \cdot 100 \mathrm{~g}^{-1}\right)$ & 37.0 & 73.0 & 89.0 \\
Ash $\left(\mathrm{g} \cdot 100 \mathrm{~g}^{-1}\right)$ & 8.5 & 7.9 & 7.5 \\
Lactose $\left(\mathrm{g} \cdot 100 \mathrm{~g}^{-1}\right)$ & 53.0 & 17.0 & 2.3 \\
Calcium & 89.0 & 69.0 & 65.0 \\
$\left(\mathrm{mmol} \cdot 100 \mathrm{~g} \mathrm{protein}^{-1}\right)$ & & & \\
\hline
\end{tabular}

also improved stability of the solubility of the product during prolonged storage.

A number of studies on the roles of calcium and phosphate in the casein micelle have been conducted. Reduction of calcium by dialysis (against EDTA) resulted in an increase in casein in the serum compared with the micelles. However, large micelles were still observed [20] and the size distribution of the micelles was claimed to be hardly affected. It can be deduced that the binding forces within the micelle are reduced as the colloidal calcium is reduced.

There have been a number of studies on the effects of the addition of $\mathrm{NaCl}$ to milk, concentrated milk and micellar casein. With the addition of $\mathrm{NaCl}$, the hydration 
at $4{ }^{\circ} \mathrm{C}$ of the micellar casein was found to increase from 200 to $220 \mathrm{~g} \mathrm{H}_{2} \mathrm{O} \cdot \mathrm{g}_{\text {protein }}{ }^{-1}$ [21] and the voluminosity at $30{ }^{\circ} \mathrm{C}$ was found to increase from 3.26 to $3.40 \mathrm{~mL} \cdot \mathrm{g}^{-1}$ [44].

Addition of sodium to milk has effects on the distribution of mineral ions. Aoki et al. [7] studied the effects of $\mathrm{NaCl}(0.1$ and $0.3 \mathrm{~mol} \cdot \mathrm{L}^{-1}$ ) on skim milks and casein micelle dispersions made from centrifuged casein micelles redispersed in simulated milk ultrafiltrates. The addition of $\mathrm{NaCl}$ resulted in an increase in soluble calcium and inorganic phosphate. It also resulted in a decrease in the proportion of casein in the micelle fraction, as observed by gel chromatography (in the presence of urea), indicating that the addition of $\mathrm{NaCl}$ loosened the structure of the casein micelles.

Gaucheron et al. [18] observed, using concentrated native casein micelle suspensions, very pronounced increases in $\mathrm{Ca}^{2+}$ and $\mathrm{Mg}^{2+}$ in the aqueous phase with the addition of $\mathrm{NaCl}$. The inorganic phosphorus also increased, but to a much lesser extent, leading to an increase in the molar ratio of solubilised calcium to inorganic phosphorus. Similar increases in calcium and inorganic phosphorus in the soluble phase with the addition of $\mathrm{NaCl}$ (up to $0.6 \mathrm{~mol} \cdot \mathrm{L}^{-1}$ ) were observed with $2 \times$ concentrated milks [26]. The zeta potential decreased markedly, but the average casein micelle size remained unchanged.

The effect of the addition of sodium depends on where in the process it is added. $\mathrm{NaCl}$ is more effective if it is included in the concentrate and dried with the milk solution [42]. It can be deduced that $\mathrm{NaCl}$ is most effective when it alters the binding forces within the micelle during drying.

\section{PROTEIN INSOLUBILITY MECHANISM}

The insolubility reaction may arise at the particle surface, between the micelles or at the scale of the protein molecules. Further work is required to elucidate the mechanism.
What is clear is that the ionic environment plays a part in the development of insolubility in casein both in drying and in storage. It is possible that the effect on the protein arises from changes in the orientation of the $\kappa$-casein, primarily located at the micelle surface; in unaltered milk, these molecules stabilise the micelles and prevent aggregation. This explanation is in accord with the observed behaviour of the reconstituted particles that absorb water, but the casein micelles dissolve only slowly.

\section{IMPLICATIONS FOR DRYING}

The relative rates of development of insolubility, as shown in Figure 2, have determined the ways in which spray drying has been adapted to the drying of milk powder products:

(a) Drying is done using co-current spray driers, despite countercurrent driers being more energy efficient. The rapid reduction in the drying air temperature, when the air is mixed with the spray of concentrate, results in lower temperatures during the drying process.

(b) A minimum residence time while the particles are traversing the moisture content zone from 40 to $15 \mathrm{~g} \cdot 100 \mathrm{~g}$ product $^{-1}$.

(c) Withdrawing powder out of the spray drier at an elevated moisture content, as when secondary drying is employed, allows higher humidity and lower air and particle temperatures in the chamber.

(d) Fluid bed secondary driers can run at moderate temperatures without detriment to the powder.

(e) Fine particles from the spray drier and the fluid bed drier can be returned to the atomisation zone for agglomeration, as the dry powder is resistant to heat.

The behaviour of the casein proteins also places restrictions on the types of driers that 
can be used successfully for producing milk powder. It is difficult to produce powders with acceptable solubility from driers that operate at higher temperatures, such as drum driers and driers operating with superheated steam.

Products made with reduced calcium contents require different processing conditions from standard products, and these conditions may need to be optimised as energy costs increase and waste management issues receive increased attention.

\section{CONCLUSIONS}

The marked differences in the sensitivity to drying of MPC85, MPC70 and SMP arise from the very marked differences in the concentration of lactose, which can act within the micelles both as a spacer and as a hydrogen-bonding species.

The mechanism of insolubility development in the casein protein in milk products has not been fully explained. It is likely to arise from changes in the conformation of the protein molecules to more hydrophobic forms. As well as heat and time of exposure, the extent of the changes is influenced by the ionic environment and by the presence of lactose. Studies utilising individual caseins, or mathematical modelling, may be needed to elucidate the roles of the various components free from the complexities of the milk micelle structure.

Manipulation of the drying conditions and manipulation of the composition can be used to probe the insolubility phenomenon in milk powder products. Information on a number of aspects - the dehydration process, product physical and chemical properties, solubility measurements, instrumental measurements and transmission electron microscopy - is required to give a complete picture of the phenomenon. Both the changes occurring in the drying process and the changes observed in the dry powder during storage require further study.
Great care needs to be taken to avoid correlating phenomena that are not necessarily causally associated.

Acknowledgements: I wish to acknowledge the support of the Fonterra Research Centre and the work of colleagues S. Anema, V. Bhaskar, A. Carr, A. Fletcher, J. Harper, P. Havea, Y. Hemar, R. Hunter, D. Love, D. Newstead, A. MacGibbon, A. McKenna, D. Otter, S. Ram, A. Rogers, C. Thompson and G. Truong on protein solubility over a number of years.

\section{REFERENCES}

[1] Allison S.D., Chang B., Randolph T.W., Carpenter J.F., Hydrogen bonding between sugar and protein is responsible for inhibition of dehydration-induced protein unfolding, Arch. Biochem. Biophys. 365 (1999) 289-298.

[2] Allison S.D., Dong A., Carpenter J.F., Counteracting effects of thiocyanate and sucrose on chymotrypsinogen secondary structure and aggregation during freezing, drying, and rehydration, Biophys. J. 71 (1996) 2022-2032.

[3] American Dry Milk Institute, Determination of solubility index, in: Bulletin 916 (Revised), Standards for Grades of Dry Milks Including Methods of Analysis, American Dry Milk Institute Inc., Chicago, Illinois, USA, 1971, pp. 26-27.

[4] Aneja R.P., Equipment for recombination, in: Recombination of Milk and Milk Products, Alexandria, Egypt, 12-16 November 1988, Special Issue 9001, Int. Dairy Fed., Brussels, Belgium, 1988, pp. 186-195.

[5] Anema S.G., Li Y., Re-equilibration of the minerals in skim milk during reconstitution, Milchwissenschaft 58 (2003) 174-178.

[6] Anema S.G., Pinder D.N., Hunter R.J., Hemar Y., Effects of storage temperature on the solubility of milk protein concentrate (MPC85), Food Hydrocoll. 20 (2006) 386-393.

[7] Aoki T., Umeda T., Nakano T., Effect of sodium chloride on the properties of casein micelles, Milchwissenschaft 54 (1999) 91-93.

[8] Baldwin A., Pearce D., Milk powder, in: Onwulata C. (Ed.), Encapsulated and Powdered Foods, Taylor \& Francis, Boca Raton, Florida, USA, 2005, pp. 387-433. 
[9] Baldwin A.J., Truong G.N.T., Development of insolubility in dehydration of dairy milk powders, Food Bioprod. Process. 85 (C3) (2007) 202-208.

[10] Cho Y., Singh H., Creamer L.K., Heatinduced interactions of $\beta$-lactoglobulin A and $\kappa$-casein B in a model system, J. Dairy Res. 70 (2003) 61-71.

[11] Creighton T.E., Proteins: Structures and Molecular Principles, W.H. Freeman and Co., New York, USA, 1984, pp. 139-152.

[12] de Kruif C.G., Holt C., Casein micelle structure, functions and interactions, in: Fox P.F., McSweeney P.L.H. (Eds.), Advanced Dairy Chemistry. 1. Proteins, Part A, 3rd edn., Kluwer Academic/Plenum Publishers, New York, USA, 2003, pp. 233276.

[13] Edsall J.T., McKenzie H.A., Water and proteins. II. The location and dynamics of water in protein systems and its relation to their stability and properties, Adv. Biophys. 16 (1983) 53-183.

[14] Eino M., The manufacture of recombined condensed milk, in: Recombination of Milk and Milk Products, Alexandria, Egypt, 12-16 November 1988, Special Issue 9001, Int. Dairy Fed., Brussels, Belgium, 1990, pp. 351-363.

[15] Ellis J.R., Prillig E.B., Amann A.H., Tablet coating, in: Lachman L., Lieberman H.A., Karig J.L. (Eds.), The Theory and Practice of Industrial Pharmacy, 2nd edn., Lea \& Febiger, Philadelphia, Pennsylvania, USA, 1976, pp. 359-388.

[16] Fox P.F., Brodkorb A., The casein micelle: historical aspects, current concepts and significance, Int. Dairy J. 18 (2008) 677-684.

[17] Gaiani C., Schuck P., Scher J., Desobry S., Banon S., Dairy powder rehydration: influence of protein state, incorporation mode, and agglomeration, J. Dairy Sci. 90 (2007) 570-581.

[18] Gaucheron F., Le Graet Y., Briard V., Effect of $\mathrm{NaCl}$ addition on the mineral equilibrium of concentrated and acidified casein micelles, Milchwissenschaft 55 (2000) 82-86.

[19] Gregory R.B., Protein hydration and glass transitions, in: Reid D.S. (Ed.), The Properties of Water in Foods ISOPOW 6, Blackie Academic \& Professional, London, UK, 1998, pp. 57-99.

[20] Griffin M.C.A., Lyster R.L.J., Price J.C., The disaggregation of calcium-depleted casein micelles, Eur. J. Biochem. 174 (1988) 339-343.

[21] Grufferty M.B., Fox P.F., Effect of added $\mathrm{NaCl}$ on some physicochemical properties of milk, Ir. J. Food Sci. Technol. 9 (1985) 1-9.

[22] Hall C.W., Hedrick T.I., Drying of Milk and Milk Products, 2nd edn., AVI Publishing Co. Inc., Westport, Connecticut, USA, 1971, pp. 103-105, 215-216.

[23] Harland H.A., Coulter S.T., Jenness R., The effect of the various steps in the manufacture on the extent of serum protein denaturation in nonfat dry milk solids, J. Dairy Sci. 35 (1952) 363-368.

[24] Havea P., Protein interactions in milk protein concentrate powders, Int. Dairy J. 16 (2006) 415-422.

[25] Horne D.S., Casein interactions: casting light on the black boxes, the structure in dairy products, Int. Dairy J. 8 (1998) 171-177.

[26] Huppertz T., Fox P.F., Effect of $\mathrm{NaCl}$ on some physico-chemical properties of concentrated bovine milk, Int. Dairy J. 16 (2006) 1142-1148.

[27] International Dairy Federation, Dried milk and dried milk products - determination of insolubility index, IDF Standard 129, Int. Dairy Fed., Brussels, Belgium, 2005.

[28] Jeantet R., Schuck P., Six T., Andre C., Delaplace G., The influence of stirring speed, temperature and solid concentration on the rehydration time of micellar casein powder, Dairy Sci. Technol., DOI: 10.1051/ dst $/ 2009043$

[29] Kudo N., Hols G., van Mil P.J.J.M., The insolubility index of moist skim milk powder: influence of the temperature of the secondary drying air, Neth. Milk Dairy J. 44 (1990) 89-98

[30] Kunz I.D., The physical properties of water associated with biomacromolecules, in: Duckworth R.B. (Ed.), Water Relations of Foods, Academic Press, London, UK, 1974, pp. 93-109.

[31] Lampitt L.H., Bushill J.H., The physicochemical constitution of milk powder, Analyst 56 (1931) 778-794.

[32] Martin G.J.O., Williams R.P.W., Dunstan D.E., Comparison of casein micelles in raw and reconstituted skim milk, J. Dairy Sci. 90 (2007) 4543-4551.

[33] McKenna A.B., Effects of processing and storage on the reconstitution properties of whole milk and ultrafiltered skim milk 
powders, Ph.D. Thesis, Massey University, Palmerston North, New Zealand, 2000.

[34] New Zealand Dairy Board, Milk protein products and process, Patent WO 01/41578, 2001.

[35] New Zealand Dairy Board, Monovalent salt enhances solubility of milk protein concentrate, Patent WO 02/096208, 2002.

[36] Nielsen L.S., Fee C.J., Chen X.D., The effects of temperature and holding time of external heating on solubility deterioration of a skim milk powder, Trans. IChemE 74 (Part C) (1996) 159-162.

[37] Patel H.A., Singh H., Anema S.G., Creamer L.K., Effects of heat and high hydrostatic pressure treatments on disulfide bonding interchanges among the proteins in skim milk, J. Agric. Food Chem. 54 (2006) 34093420 .

[38] Pisecky J., Handbook of Milk Powder Manufacture, Niro A/S, Copenhagen, Denmark, 1997, pp. 151-153.

[39] Prestrelski S.J., Tedeschi N., Arakawa T., Carpenter J.F., Dehydration-induced conformational transitions in proteins and their inhibition by stabilizers, Biophys. J. 65 (1993) 661-671.

[40] Qi P.X., Studies of casein micelle structure: the past and the present, Lait 87 (2007) 363-383.

[41] Rahman M.S., Glass transition data and models of foods, in: Rahman M.S. (Ed.),
Food Properties Handbook, 2nd edn., CRC Press, Boca Raton, Florida, USA, 2009, p. 268.

[42] Schuck P., Davenel A., Mariette F., Briard V., Méjean S., Piot M., Rehydration of casein powders: effects of added mineral salts and salt addition methods on water transfer, Int. Dairy J. 12 (2002) 51-57.

[43] Schuck P., Piot M., Méjean S., Le Graët Y., Fauquant J., Brulé G., Maubois J.-L., Déshydratation par atomisation de phosphocaséinate natif obtenu par microfiltration sur membrane, Lait 74 (1994) 375-388.

[44] van Hooydonk A.C.M., Hagedoorn H.G., Boerrigter I.J., The effect of various cations on the renneting of milk, Neth. Milk Dairy J. 40 (1986) 369-390.

[45] Walstra P., Casein sub-micelles: do they exist?, Int. Dairy J. 9 (1999) 189-192.

[46] Walstra P., Jenness R., Dairy Chemistry and Physics, John Wiley \& Sons, New York, USA, 1984, p. 106.

[47] Walstra P., Jenness R., Dairy Chemistry and Physics, John Wiley \& Sons, New York, USA, 1984, pp. 229-253.

[48] Walstra P., Jenness R., Dairy Chemistry and Physics, John Wiley \& Sons, New York, USA, 1984, pp. 307-309.

[49] Wright N.C., Factors affecting the solubility of milk powders. 1 . The effect of heat on the solubility of milk proteins, J. Dairy Res. 4 (1933) 122-141. 